\title{
SIMPLICITY AND INNOVATION IN THE LAW OF EQUITY AND TRUSTS: THE COOKE ERA
}

\author{
Andrew S Butler*
}

This essay explores the contribution that Robin Cooke and his erstwhile colleagues on the Court of Appeal bench made in the field of equity and trusts. The survey of key equity and trusts cases of the Cooke era demonstrates a commitment to principle, with an emphasis on the purpose of individual equitable and trusts doctrines and a close examination of the individual facts of each case. The result is that the law of equity and trusts is now more principled in focus and simpler to state.

\section{INTRODUCTION}

This volume justly celebrates the work of a man considered by many to be New Zealand's finest jurist, Robin Cooke. ${ }^{1}$ Large parts of New Zealand law benefited from Robin's broad knowledge of the legal system and his ability to concentrate on the big themes, whether that was as an academic, as a member of a law reform body or as a judge. His goal in these roles was aptly summarised in the title of the 1997 Legal Research Foundation seminar organised to commemorate the Cooke era in New Zealand Law: "The Struggle for Simplicity". Of course, simplicity is not to be confused with simplistic. The object was to find a simple and elegant way of expressing what the law was trying to achieve through any particular doctrine; once having expressed the broad principle (or principles) informing a particular doctrine, a determined focus on the specific facts of each case, with all the nuance and colour that they may evoke, was required. Moreover, it might be possible, indeed necessary, to apply the doctrine in an innovative way if equity was to ensure that the object so identified continued to be realised.

* $\quad$ BCL (NUI, Dub), LLM (Osgoode), PhD (EUI, Florence). Partner, Russell McVeagh, Wellington. Andrew is formerly a senior lecturer at the Victoria University of Wellington's Faculty of Law. He has written on topics related to equity and trusts, including being general editor of, and a contributor to, Equity and Trusts in New Zealand (Brookers, Wellington, 2003).

1 Dame Sian Elias "In Memoriam, Lord Cooke of Thorndon" (2006) 22 NZULR 181; "NZ's Greatest Jurist Dies: Lord Cooke" (18 September 2006) 674 Law Talk 6. 
One area that particularly benefited from Robin's struggle for simplicity and openness to innovation during his period on the bench was the law of equity and trusts. Though eschewing any pretension at being an equity specialist, the area clearly held quite some fascination for him. ${ }^{2}$ Through it, he could explore issues that were at the core of his sense of judging: the identification of the real purpose or object of a particular doctrine; a close analysis of the particular facts of the case before him to see how the doctrine should be applied; an emphasis on what expectations persons in the shoes of the parties would have (including, where relevant, reference to contemporary mores and understandings); a questioning of the utility of accumulated special and precise rules if they "fail to meet the wider demands which are their ultimate justification"; 3 a sense of justice centred, in the case of equity and trusts law, on the conscience of the defendant. Moreover, he was assisted in pursuing these themes by his ability to look around the Commonwealth for an appreciation of possible solutions and responses that might be different from those to be found in judgments of the English courts. ${ }^{4}$

I have been asked to consider the contribution that Robin and his erstwhile colleagues on the Court of Appeal bench made towards the principled development of equity and trusts law.

\section{THE STATE OF EQUITY AND TRUSTS PRIOR TO THE COOKE ERA}

Though usually explained as being a doctrine of law aimed at mollifying the excessive rigidity of the common law, equity too succumbed to the suffocating influences of what Lord Wilberforce described in another context, and in a phrase dear to Robin, as the "austerity of tabulated legalism". 5

Aspects of this were inevitable. After all, much of the law of trusts developed, certainly in the $18^{\text {th }}$ and $19^{\text {th }}$ centuries, in the context of complex property holding schemes drawn together as part of marriage settlements. Once property is at stake, the tendency for complexity increases. The accretion of case upon case created a quagmire. Equally, industrialisation and the growth of capitalism meant that equitable responses to contracting practices underwent strong re-examination and challenge to ensure they were "fit for purpose". Of course, where there was dispute as to what those purposes were (as was indeed the case for much of the $19^{\text {th }}$ and early $20^{\text {th }}$ centuries) complexity was inevitable.

2 R Cooke "The Place of Equity and Equitable Doctrines in the Contemporary Common Law World: A New Zealand perspective" in T Youdan (ed) Equity, Fiduciaries and Trusts (Carswell, Toronto, 1993) 31.

3 Ibid, 27.

4 Ibid, 27. See also, R Cooke "Fairness" (1989) 19 VUWLR 421, 430-433 (a discussion of the connections between fairness and constructive trusts, with a particular emphasis on the role to be played by conscience and the particular facts of each case).

5 Minister of Home Affairs $v$ Fisher [1980] AC 319, 328 (PC) Lord Wilberforce, referred to in, for example, New Zealand Maori Council v Attorney-General [1987] 1 NZLR 641, 655 (CA) Cooke P and MOT v Noort [1992] 3 NZLR 260, 268 (CA) Cooke P. 
Other matters were not inevitable, but their occurrence was at least understandable if not welcome. So, for example, the separation of Chancery and common law courts in England (and a number of overseas jurisdictions) introduced a capacity for dissonance in pleadings, practice and procedure that was not conducive to speedy or rational decision-making. The horrors of Chancery practice in the Victorian era are well parodied in Charles Dickens' Bleak House. In many ways all that was fictional about Jarndyce $v$ Jarndyce was the case name. In addition, the flourishing in the nineteenth century of legal treatise writing, with its goal of a scientific exposition of relevant areas of law, led to an approach of "treating the trust as an abstract and singular concept distinct from the various contexts in which it arises". 6

Nor was the problem one confined solely to the law of trusts. In fields such as equitable estoppel and constructive trusts judges had become hidebound by judicially encrusted requirements. Take equitable estoppel. As James Palmer has noted: ${ }^{7}$

Estoppel has a complicated history. Although a broad unified doctrine of equitable estoppel may now be talked about with some certainty, at least 16 different doctrines of estoppel each with distinct triggering requirements and remedial possibilities, have received judicial recognition. ... The inconsistent use of terminology, together with the evolution of these various doctrines over time has left behind a jumble of principles, rules, and maxims.

Third, though the enactment of the Judicature Acts in the 1870s in England was meant to result in equitable doctrines and remedies being administered in all of Her Majesty's courts, not all practitioners or judges were capable of, or well disposed towards, doing so. The result was that although it was provided that in the case of conflict between a rule of equity and a rule of common law the former should prevail, one way of reducing the risk of conflict was to confine the potential application of an equitable rule by encrusting upon on it limitations and requirements - in that way the likelihood that equity would cut across relevant common law rules was minimised.

\section{THE PUSH FOR SIMPLE, PRACTICAL JUSTICE IN EQUITY AND TRUSTS}

The state of equitable doctrine in New Zealand was not much different in the early 1970s when Robin Cooke was appointed to the Supreme Court bench. Whereas in England constructive trusts had been controversially used to achieve justice in respect of property interests in the matrimonial home when the marriage failed, in New Zealand there was no call for a similar development largely as a result of the existence of a separate statutory jurisdiction (under the Matrimonial Property Act 1963) that permitted the courts to do justice in such circumstances. Nor were arguments in respect of other equitable doctrines in novel circumstances particularly successful, if they were tried at all.

6 P Parkinson "Chaos in the Law of Trust: Book Review of Ford \& Lee's Principles of the Law of Trusts" (1991) 13 Syd L Rev 227, 230.

7 J Palmer "Equitable estoppel" in A S Butler (ed) Equity and Trusts in New Zealand (Brookers, Wellington, 2003) 485 (footnotes omitted). 
And of course the presence of the Privy Council as the ultimate arbiter of New Zealand civil litigation meant that counsel and judges had to have an eye to what was likely to be acceptable reasoning before their Lordships in London. But as Robin Cooke assumed judicial office the preparedness of judges to revisit the basis for existing doctrines and rules of law (including equity) was evolving. Equity and trusts was to prove a fruitful field for such endeavours.

\section{A Re Richards (dec'd): Early Signs of Things to Come}

In his tribute to Robin, Ted Thomas expressed the view that, prior to assuming the presidency of the Court of Appeal, Robin "was unduly constrained by a faintly ingrained tendency to adopt a formalistic methodology". ${ }^{8}$ Whether that is accurate others are far better placed to judge than I am. But it certainly was not apparent in one of Robin's early judgments as a Supreme Court judge, Re Richards (deceased). ${ }^{9}$

The case concerned the capital-income distinction in trusts law in the particularly difficult context of a farming business. The primary issue was whether the value of surplus livestock (sheep and cattle) was to be held for the life tenant or for the remaindermen. The area was notoriously difficult and cases could be found to support almost any view. After a thorough review of the case law, Robin noted in his judgment (in a somewhat understated way): "An overall review of the reported cases may suggest some difference of emphasis and even a lack of clarity and consistency." ${ }^{10}$ In the face of apparently conflicting authority, he was undaunted, because principle showed the way forward: ${ }^{11}$

... I think there emerges a tolerably clear result, and something approaching a reconciliation, if one bears firmly in mind that the paramount principle is even-handedness [as between different classes of beneficiaries], but in a context of testamentary authority to carry on a farming business.

The rest of his judgment was directed at giving effect to this simple statement of guiding principle, through a series of propositions as to the proper approach to accounting for standard values in "surplus stock" cases. And, as the leading Australian text on trusts records, the result was a judgment that is "perhaps the best of the existing cases to bring some measure of reconciliation and clarity to the existing case law." ${ }^{12}$ Re Richards, then, was a sign of things to come.

8 EW Thomas QC "A personal tribute to the late Robin Cooke" 353 (October 2006) Council Brief 6.

9 Re Richards (deceased) [1974] 2 NZLR 60 (SC).

10 Ibid, 75 Cooke J.

11 Ibid.

12 HAJ Ford and WA Lee Principles of the Law of Trusts (looseleaf, Law Book Co, North Ryde, NSW) para 11300 . 


\section{B Apportionment: Day v Mead}

The Contributory Negligence Act 1947 permits a court to reduce the amount of damages payable by a defendant in recognition of the contribution to the plaintiff's losses which the plaintiff him or herself has contributed. The Act, however, does not apply to the remedies of equitable compensation or account of profits. In Day v Mead, ${ }^{13}$ that omission was not seen as critical by the Court of Appeal.

Briefly, the facts in Day were that D had approached M, his solicitor, for a vehicle in which he could invest money. M suggested investment in a particular company, but omitted to mention that D's investment (in two tranches of $\$ 20,000$ and $\$ 80,000$ ) were to be used to discharge loans that $M$ had made on behalf of other clients. $\mathrm{M}$ was found to have breached his fiduciary duty to $\mathrm{D}$ in failing to advise D of the intended use to which D's money would be put (there was a clear conflict of interest between M's duty to D and his duty to other clients, whose loans were discharged by D's investments) and failing to advise $\mathrm{D}$ to obtain independent advice in making his initial investment.

At trial, however, the judge found that by the time of his second investment of $\$ 80,000$, D had acquired considerable knowledge of the company and ought to have taken steps to more carefully assess risks to his investment. In the result, the trial judge held D to have contributed to his own loss in the second investment and applied a discount of $50 \%$.

On appeal, the Court of Appeal upheld the discount applied by the trial judge. In his judgment, for three of his four colleagues, Cooke P stated: ${ }^{14}$

Whether or not there are reported cases in which compensation for breach of fiduciary obligation has been assessed on the footing that the plaintiff should accept some share of the responsibility, there appears to be no solid reason for denying jurisdiction to follow that obviously just course, especially now that law and equity have mingled or are interacting. It is an opportunity for equity to show that it has not petrified and to live up to the spirit of its maxims. Moreover, assuming that the Act does not itself apply, it is nevertheless helpful as an analogy, on the principle to which we in New Zealand are increasingly giving weight that the evolution of judge-made law may be influenced by the ideas of the legislature as reflected in contemporary statutes and by other current trends.

The passage is striking for a number of features. First, it emphasises that the absence of precedent establishing the point was not regarded as critical to the proper resolution of the issue before the court. If a particular innovation is not inconsistent with the state of the law, and in fact would enhance the law's ability to achieve its purpose, then it can be adopted. In short, equity "has not petrified". ${ }^{15}$ Second, the justice of applying the concept of contribution to an equitable claim

13 Day v Mead [1987] 2 NZLR 443 (CA).

14 Ibid, 451 Cooke P.

15 Ibid. 
was established by reference to the fact that such a course was available in respect of common law actions. This underscores the point that equity should be seen a part of the whole fabric of the legal system, not just simply a field isolated on its own. Accordingly, in applying equitable jurisdiction, the courts were to have regard to relevant common law and legislative developments.

In his concurring judgment Somers J eschewed Cooke P's indirect analogy with contribution principles applied to common law claims and preferred a somewhat more direct approach, based on equitable considerations of fairness. He stated: ${ }^{16}$

I have, however, formed the view from a reading of the evidence and the judgment as a whole that it would be unjust and unfair to impose total liability on Mr Mead. There was a degree of want of care for his own property on Mr Day's part which goes beyond reliance on $\mathrm{Mr}$ Mead and approaches acquiescence in the risk involved in the second investment.

While superficially at least not so innovative, Somers J's judgment reflects a deep understanding that equitable relief must be applied in a manner which avoids injustice and unfairness to a defendant.

The innovation given effect to in Day $v$ Mead has proven attractive to judges in later New Zealand cases and has been applied on numerous occasions. ${ }^{17}$ In addition, the Day v Mead approach has attracted interest overseas.

In Canada, support for the approach adopted in Day $v$ Mead was given by La Forest $\mathrm{J}$ in his judgment in Canson Enterprises Ltd v Broughton \& Co. ${ }^{18}$ He viewed it as a natural progression of the maxim that equity follows the law, particularly in those fields where the facts would support concurrent findings of breach of tort/contract and of equitable duties.

In Australia, however, the reaction has been, by and large, dismissive. The authors of the leading Australian text, Meagher, Gummow and Lehane's Equity: Doctrines and Remedies have expressed the view that the decision in Day $v$ Mead is "surprising"19 and have quoted approvingly an extrajudicial comment by Handley JA that the decision is "clearly wrong". ${ }^{20}$ Indeed in Pilmer $v$ The Duke Group Ltd (in liquidation) a majority of the High Court of Australia indicated that there were

16 Ibid, 462 Somers J.

17 See Butler, above n 7, 858-861.

18 Canson Enterprises Ltd v Broughton \& Co (1991) 85 DLR (4th) 129, 151-153 (SCC).

19 RP Meagher, JD Heydon and MJ Leeming Meagher, Gummow and Lehane's Equity: Doctrines and Remedies (4 ed, Butterworths Lexis Nexis, Sydney, 2002) 838.

20 Ibid, 839, citing KR Handley "Reduction of damages awards" in PD Finn (ed) Essays on Damages (LBC, Sydney, 1992) 127. The commentary has not been uniformly critical; Sir Anthony Mason has supported the concept in extra-judicial writings. See, for example, A Mason "The Place of Equity and Equitable Remedies in the Contemporary Common Law World" (1994) 110 LQR 238, 244. 
"severe conceptual difficulties" to accepting apportionment for contributory negligence in respect of equitable breaches of duty. ${ }^{21}$

Its detractors say that several difficulties arise in respect of the Day v Mead approach. First, there is substantial scepticism as to the juristic basis for the fusion of law and equity which in part informed Cooke P's approach. Second, contribution is regarded as incompatible with the view that fiduciary law is designed to protect the vulnerable against those who can take advantage of them. Third, it has been argued that any extension of the contribution doctrine is a matter for Parliament, not the courts.

With respect, these points fail to convince and certainly do not establish the proposition that equity should, under no circumstances, reduce an award of equitable damages in recognition of the plaintiff's contributory negligence. First, as to the fusion debate, it has to be accepted that equity does not occupy a time warp. What counts is not why, historically, certain positions were adopted in equity, but rather whether those positions ought to be maintained in light of modern conditions. Among those modern conditions is the test of legal rationality, which asks whether there is a principled reason for the position to be maintained. One of the considerations relevant to that is whether a particular component of the legal system is operating in a manner cognisant of the rules and principles operating in other areas. Second, the fact that fiduciary law is typically characterised as protecting the vulnerable can be accepted without undermining the recognition, in appropriate circumstances, that the plaintiff did have the means, at a particular point in time, to take measures to protect him or herself. Third, the exercise of equitable relief has always been discretionary. Contribution as a concept recognises the injustice to a defendant of requiring him or her to recompense the plaintiff for total losses that the plaintiff has suffered, even though a substantial cause of the losses was the plaintiff's own lack of care for his or her interests, recognising that fundamental unfairness in the exercise of equitable remedial jurisdiction does not require legislative approval; in equity, there has always been a legitimate jurisdictional hook for contribution to be recognised and given effect to. The fact that legislative action was required to achieve that result in respect of common law and statutory remedies is simply a function of the different basis for the exercise of remedial jurisdiction at common law; it is not a reason to say that before equity can give effect to the concept it needs Parliamentary permission.

\section{Exemplary Damages: Aquaculture Corp v NZ Green Mussel Co}

A further illustration of the pursuit of simplicity and the elimination of anomaly is the Court of Appeal's move to recognise the possibility for the award of exemplary damages in respect of breaches of equitable duty.

21 Pilmer v The Duke Group Ltd (in liquidation) (2001) 207 CLR 165, para 86 McHugh, Gummow, Hayne and Callinan JJ. 
As many readers will be aware, the philosophical basis for, utility of, and fairness of an exemplary damages award in civil proceedings is a matter of considerable debate. In New Zealand, however, the Courts have embraced the exemplary damages concept and have made awards in respect of a range of torts when satisfied that a plaintiff has acted in a highhanded or contumacious way. Indeed, in New Zealand it would appear that exemplary damages may well be available in (albeit rare) cases of negligence and deliberate breach of contract. ${ }^{22}$

In Aquaculture Corp v NZ Green Mussel Co Ltd the question arose as to whether exemplary damages were available for breach of an equitable duty of confidence. ${ }^{23}$ On appeal, the trial judge's award of exemplary damages was substituted with a significantly higher compensatory award of $\$ 1.5$ million. ${ }^{24}$ However, Cooke $\mathrm{P}$ for four of the five judges stated that he could see no reason in principle why exemplary damages should not be awarded for an actionable breach of confidence, if a compensatory award would not adequately reflect the gravity of the defendant's conduct. ${ }^{25}$ In his separate judgment, Somers J expressed greater reluctance to concede that exemplary damages were available for breach of equitable duty. In his view "equity and penalty are strangers", ${ }^{26}$ suggesting that equity saw no role for exemplary damages.

In later cases, however, Cooke P's approach has prevailed. So, for example, in Cook v Evatt (No 2), Fisher $\mathrm{J}$ accepted that exemplary damages were available for a breach of fiduciary duty. In that case an investment adviser had earned a secret profit in breach of his duty of loyalty to the plaintiff. Having reminded himself of the general matters that had to be satisfied before exemplary damages were imposed, ${ }^{27}$ Fisher $\mathrm{J}$ observed that in the case of breach of fiduciary duty, "the additional step of demonstrating punishable conduct may be a relatively short one compared with most other classes of action". ${ }^{28}$ That is because in many cases the whole basis for the existence of the duty is the situational vulnerability of the plaintiff and deliberate advantage-taking of that vulnerability goes a long way to supporting an award of exemplary damages. On the facts, Fisher J held that the first defendant should pay $\$ 5,000$ exemplary damages.

22 Ellison v L [1998] 1 NZLR 416 (CA) and Tak \& Co Inc v AEL Corp Ltd (1995) NZBLC 103,887 (HC) respectively.

23 Aquaculture Corp v NZ Green Mussel Co Ltd [1990] 3 NZLR 299 (CA).

24 At trial, the High Court had awarded \$100,000 exemplary damages in respect of a proven breach of confidence. Ibid, 300 .

25 Ibid, 302 Cooke P.

26 Ibid, 302 Somers J.

27 Cook v Evatt (No 2) [1992] 1 NZLR 676, 706 (HC) Fisher J.

28 Ibid. 
Again, the approach approved of by Cooke P and given effect to by other judges has attracted overseas attention. Again, as with apportionment, the overseas reaction has been mixed. In $K M v$ $H M$, La Forest $\mathrm{J}$ in the Supreme Count of Court referred approvingly to Cooke P's views in Aquaculture in support of the proposition that "[o]f course, equitable compensation to punish the gravity of a defendant's conduct [in that case breach of fiduciary duty] is available on the same basis as the common law remedy of punitive damages."29

In contrast, but again consistently with the treatment of apportionment, the reaction in Australia has been, generally speaking, unfavourable. In Bailey $v$ Namol Pty Ltd ${ }^{30}$ the approach approved in Aquaculture was noted. But the Federal Court of Appeal continued by stating that "[t]here is much to be said for the contrary view, put by Somers $\mathrm{J}$ in Aquaculture at 302, that 'equity and penalty are strangers'." 31

More recently, the approach to exemplary damages in Aquaculture was not followed by a majority of the New South Wales Court of Appeal (Spigelman P and Heydon JA, Mason P dissenting, with a stinging criticism by Heydon JA) in Harris $v$ Digital Pulse Limited. ${ }^{32}$ Among the reasons given were that an award of exemplary damages amounted to the creation of a new remedial power and it was not for the courts of New South Wales to do so; the unavailability (in New South Wales) of exemplary damages for breach of contract suggested that none should be available for breach of closely analogous fiduciary duties; to the extent that exemplary damages are a form of punishment, then they are incompatible with the role of equity (which does not, according to the majority, perform such a function); exemplary damages do not sit well with equity's philosophical discomfort with penalties; to the extent that the jurisdiction to award exemplary damages in equity was said to be based on the fusion of law and equity, that theory has not been accepted in Australia and could not justify such an innovation.

In the author's view, for so long as exemplary damages remain a feature of the private law landscape, the innovation in Aquaculture is to be welcomed. There seems little point in principle why exemplary damages should be available for the deliberate infliction of injury by way of a tort, yet not be available for equally egregious breaches of equitable duties, in an appropriate case. There is no reason in principle why equity should not have available exemplary damages as a tool to give better effect to its proscriptions. ${ }^{33}$ To say that historically equity and penalty are strangers is to

$29 K M v H M(1992) 96$ DLR (4th) 289, 337 (SCC) La Forest J.

30 Bailey v Namol Pty Ltd (1994) 53 FCR 102, 112-113 (FCA) Burchett, Gummow and O'Louglin JJ.

31 Ibid.

32 Harris $v$ Digital Pulse Limited (2003) 56 NSWLR 298. For a useful, critical analysis of the majority's reasons, see A Duggan "Exemplary Damages in Equity" (2006) 26 OJLS 303.

33 To similar effect, see (English) Law Commission Aggravated, Exemplary, and Restitutionary Damages (Rep No 247, Law Commission, London, 1997) para 5.55. 
simply record an historical fact; it does not, in itself, provide a philosophical basis for rejecting a jurisdiction to award exemplary damages.

Moreover, even if the historical legacy justified caution, that proposition itself does not justify complete hostility towards exemplary damages in equity. First, the strict (some would say harsh) causation rules applicable to equitable duties, such as fiduciary duties and accounting for trust assets, often result in a defendant being required to pay a type of penalty: the courts assume a worst case scenario against a defaulting fiduciary or trustee and require him or her to account accordingly. In many cases the de facto result will be to impose a penalty on the defendant.

Secondly, the language of "penalty" would rarely be appropriate to describe what New Zealand Courts do when awarding exemplary damages. New Zealand practice is that exemplary damages are modest in amount, typically in a range of $\$ 15,000$ to $\$ 30,000$. Indeed, awards lower than this range are not unknown, as the award of \$5,000 in Cook v Evatt (No 2) referred to earlier illustrates. That being the case, in New Zealand exemplary damages are typically a vehicle to mark the highhandedness of a defendant's conduct, rather than to severely punish him or her for that conduct. Moreover, it is important to emphasise that acceptance that exemplary damages can be awarded does not mean that they will be routinely awarded: the circumstances justifying their award for breach of fiduciary duties should be considered by reference to the usual factors that determine their award in respect of common law and statutory claims. ${ }^{34}$

\section{Unconscientious Retention of Property: Elders Pastoral}

Elders Pastoral Ltd v Bank of New Zealand involved an arrangement whereby a farmer, G, obtained a loan from the BNZ secured over his farm stock by way of a registered security. ${ }^{35} \mathrm{G}$ was, at the time, indebted to a number of parties including BNZ and Elders. It was Elders that persuaded BNZ to provide the loan. The effect of the security instrument was that G covenanted not, without the prior written consent of BNZ, to sell any part of his stock except in the ordinary course of business; and that in the absence of any direction to the contrary by BNZ, all money payable in respect of the sale of stock should be paid to BNZ (clause 15). Subsequently, G, through Elders, his stock agents, sold some progeny of the sheep assigned to BNZ under the security instrument. From the proceeds of sale Elders retained the costs of sale, together with almost all of the balance of the proceeds, which it applied in satisfaction of G's indebtedness to Elders. A small sum was left over and paid to BNZ. BNZ sought summary judgment for the proceeds retained by Elders. It alleged that BNZ had an equitable interest in the proceeds of sale, with the concomitant right to trace those proceeds against Elders.

34 See Duggan, above n 32 to similar effect.

35 Elders Pastoral Ltd v Bank of New Zealand [1989] 2 NZLR 180 (CA). 
The High Court held in favour of BNZ and, on further appeal, the High Court judgment was upheld. Elders appealed further to the Privy Council, but was unsuccessful.

In the Court of Appeal, it was held that clause 15 of the security instrument did not go so far as to amount to a contract by $\mathrm{G}$ to assign a future chose in action. (In the Privy Council, in contrast, a different view prevailed and the appeal before that court was resolved on the basis that clause 15 amounted to a clear assignment of a future chose in action of which Elders had statutory and actual notice. $)^{36}$ Of interest to this essay is the Court of Appeal's analysis of BNZ's rights as against Elders, notwithstanding its view that clause 15 did not amount to a contract to assign future property. In his judgment Cooke P noted that an assignment (or a contract to assign) was by no means the only way in which equitable rights could arise. He noted the approach of Bingham J (as he then was) in Neste Oy $v$ Lloyds Bank Plc ${ }^{37}$ to the effect that "the receiving of money which consistently with conscience cannot be retained is, in equity, sufficient to raise a trust in favour of the party for whom or in whose account it was received". ${ }^{38}$ Fastening on that statement of the law, Cooke $\mathrm{P}$ turned to the particular facts of the instant case. He accepted that Elders was taking a stand on what it believed to be its legal rights and was not engaging in deliberate sharp practice. Nonetheless, considered objectively, Cooke P formed the view that Elders' claim to retain the proceeds of sale in order to meet G's liability to it was "less than conscionable". ${ }^{39}$ Not only were they deemed to have notice of BNZ's security as a result of its registration, but in addition Elders had actual notice of the existence of the instrument. Furthermore, Elders received the proceeds of sale as the alter ego or agent for G. G had not given Elders any instruction to disregard his obligation to pay the proceeds of sale to BNZ (and, even if it had, it is unlikely that that would have made any difference).

To test his conclusion that in all the circumstances Elders should be treated as clearly being bound by the obligation of $\mathrm{G}$ to BNZ under the security instrument, Cooke P asked what reasonable people in the shoes of all three protagonists - G, BNZ and Elders - would have thought Elders' obligation was. In his view, the position was clear: ${ }^{40}$

As a matter of fair commercial dealing one can hardly imagine any reasonable party in any of the three positions, on giving thought to their relationship, having any doubt about the duty [of Elders to hold the net proceeds for BNZ to the extent of G's indebtedness to BNZ]. It seems to me a clear case for holding a constructive trust, in line after the intermingling of law and equity, both with the approach in Bingham

36 Elders Pastoral Ltd v Bank of New Zealand [1991] 1 NZLR 385 (PC).

37 Neste Oy v Lloyds Bank Plc [1983] 2 Lloyd's Rep 658 (HC).

38 Ibid, 665-6 Bingham J.

39 Elders Pastoral Ltd, above n 35, 186 Cooke P.

40 Ibid. 
J's judgment and with the general approach in this Court in such cases as Day v Mead [1987] 2 NZLR 443 and Hayward $v$ Giordani [1983] NZLR 140.

A similar approach was evident in the judgment of Somers J. He noted that some text writers had recorded that historically a pre-existing fiduciary relationship was a prerequisite to a plaintiff's claim to be able to trace property in equity. He, too, noted the comments of Bingham $\mathrm{J}$ in Neste Oy as to the operable principle of conscience. He also approved of Bingham J's view that since the fusion of law and equity, the necessity for a pre-existing fiduciary relationship as a precondition to tracing in equity made little sense. Furthermore, Somers J noted that there has always been fusion of common law and equity in New Zealand, ever since the establishment of English law. ${ }^{41}$ The effect of these developments he summarised in an important passage thus: ${ }^{42}$

Neither law nor equity is stifled by its origin. The fact that both are administered by one Court has inevitably meant that each has borrowed from the other in furthering the harmonious development of the law as a whole. I think it likely that over the years words such as unconscionable and inequitable have drawn closer to more objective concepts such as fair, reasonable and just. In some cases ... there has been a fusion in the sense that one general rule has replaced a plurality of rules. In other areas there are signs of a blending process - Day v Mead [1987] 2 NZLR 443 may come to be seen as such a case.

The constructive trust ... has not been left uninfluenced. It has come to be used as a device for imposing a liability to account on persons who cannot in good conscience retain a benefit in breach of their legal or equitable obligations. Its evolution or extension as a remedy may not yet have come to an end.

The Court of Appeal's approach has not won universal acclaim. The authors of Australia's leading text on equity, Meagher, Gummow and Lehane's Equity: Doctrines and Remedies, lead the charge, classifying the decision as a "somewhat remarkable example" of a less cautious approach to the application of fiduciary principles in commercial relationships, and expressing the view that the conclusion reached by the Court of Appeal in Elders was "very difficult to justify". 43 At home, Professor Sutton also chided the Court of Appeal's decision. He did so, however, on the somewhat narrower ground that it was inappropriate for the Court to reach adverse conclusions about the state of Elders' knowledge of G's obligations to BNZ as to the sale proceeds, without evidence having been heard about Elders knowledge when making the sale arrangements. ${ }^{44}$

The criticisms, in my view, are a little overstated. The Court of Appeal emphasised that the basis for its decision was, relatively speaking, narrow. Because it was acting as G's agent, Elders could

41 Ibid, 193 Cooke P.

42 Ibid.

43 Meagher, Heydon and Leeming, above n 19, 165.

44 R Sutton "Lord Cooke and the Academy: The View from the Law Schools" in Paul Rishworth (ed) The Struggle for Simplicity: The Cooke Era in New Zealand Law (Butterworths, Wellington, 1997) 13. 
not stand in a better position than he $\operatorname{did}{ }^{45}$ That being the case, to the extent that it would be unconscionable for $\mathrm{G}$ to retain the proceeds of sale (absent a direction from BNZ under clause 15 permitting him to do so) it was equally unconscionable for Elders to insert a right to retain them.

It is also noteworthy that although the language of the Court's judgments refers to constructive trusts, the actual remedy sought was a money judgment. Accordingly, the decision does not support the proposition that the remedy for cases similar to Elders will be anything other than personal in nature. Thus, where there is a contest between different creditors of an insolvent stock agent it could well be that a proprietary remedy would not be granted, with the result that the interests of third party unsecured creditors would not be prejudiced.

Putting these objections to one side, the decision in Elders was clearly a further important milestone on the road to a more simplified and intelligible law of equity. Instead of concentrating on the historical origin of a particular remedial device (tracing) and insisting that that device could only be utilised in respect of those particular causes of action in equity where it had traditionally been deployed, the Court of Appeal favoured an approach which focused on the object of the remedy and the underlying basis for the relationship in issue on the particular facts. The statement of the broad principle - here the unconscionable retention of moneys properly due to another - coupled with an eye for the particular facts - here Elders' status as G's agent and with statutory and actual knowledge of the security instrument - is a hallmark of the approach to equity in the Cooke era.

\section{E Goldcorp: Contract or Equity?}

In Re Goldcorp raised difficult issues of fundamental equitable principle. The case arose from the collapse of a bullion dealing company. The plaintiffs were customers who had responded to advertisements and other representations that client money would be used for the acquisition of physical bullion in forms, such as coins or ingots, chosen by the customer which would be held in safe custody in the company's vault in the customer's name. To that end, certificates of title to stored bullion were issued to individual customers; facilities for sale were made available; and withdrawal of the physical bullion could take place on short notice. The reality was rather different from the representations. The company never acquired nor set aside bullion in respect of each individual customer. Rather, a limited quantity of bullion was purchased and held in the company's vault. The company ultimately failed. It was then that the customers discovered a shortfall in the bullion held, leaving the customers several million dollars short. On the company's collapse, there was a contest between the customers and a bank which held a standard form floating charge over the company's stock in trade. In order to take priority over the bank, the customers needed to establish a proprietary interest in the company's assets. Could they?

45 Elders Pastoral Ltd v Bank of New Zealand, above n 35, 193 Cooke P. 
In the High Court, the customers lost. On appeal to the Court of Appeal, however, they succeeded, albeit by a two-one majority, with Cooke P and Gault J finding in their favour (McKay J dissenting). ${ }^{46}$

Cooke P had no doubt that on the facts of the case, particularly the representations made by the company to the customers, there was a fiduciary relationship between the parties. In his view, the contracts between the company and the customers were much more than contracts of sale and purchase or ordinary commercial contracts. The safe custody system instituted by the company, together with the representations made by the company to the customers and the way in which the company had solicited the customers to repose trust in it, meant that the situation could be regarded as "a classic example or paradigm of the assumption of fiduciary status". 47

His Honour concluded that there had been a clear breach of the fiduciary relationship in the way in which the company had acted toward its customers. The company had received customer money on trust, the purpose of which was to finance the setting aside and holding of sufficient bullion for each of them. The representations that the company had made meant it was a breach of trust for the company to receive customer money and use it for the company's general purposes without either allocating bullion to individual customers from the company's existing stocks or buying in bullion and then allocating it to individual customers. In his view, the company well knew that there was never any intention that it should have the customers' funds unless it made the allocations of bullion; the company having failed to do so, the customers retained their beneficial interests in the monies that they had provided to the company. ${ }^{48}$ Alternatively, the facts could be analysed as a case of mistaken payment: the customers were led to understand that the system operated by the company was such that bullion to which they would have title would be held for them. Put another way, the consideration stipulated for by the customers included not simply contractual rights, but rather a proprietary interest in bullion. The failure to put arrangements in place to secure their proprietary interests meant that the consideration for the customers' payments wholly failed. ${ }^{49}$

The greatest obstacle facing the customers lay in the fact that the company had paid the money which it received from them into its bank account, which was, at all relevant times, in substantial overdraft. The result was that the customers' money could not be traced into specific assets. Cooke P did not regard this as necessarily fatal to the plaintiff customers' claims. Relying on the Privy Council's decision in Space Investments Limited v Canadian Imperial Bank of Commerce Trust Co

46 Liggett $v$ Kensington [1993] 1 NZLR 257 (CA).

47 Ibid, 267 Cooke P.

48 Ibid, 271 Cooke P.

49 Ibid, 270 Cooke P. 
(Bahamas) Limited ${ }^{50}$ Cooke $\mathrm{P}$ held that it was possible for the plaintiffs to make a claim against the general assets of the company. Whether such a claim should be given priority over the rights of the debenture holding bank was to be determined by reference to who should be regarded as having taken the risk of the company's insolvency.

On the facts before the court, Cooke P was clear that the customers had no understanding that they were taking any risk of insolvency on the part of the company: to the contrary, the effect of the representations made to them by the company was that they were to acquire a proprietary interest in physical bullion which would be in their name. The bank, in contrast, as debenture holder had to be taken as having accepted some risk in relation to the assets of the company. Moreover, there was some evidence that the bank had some knowledge that the company might not be holding in its vaults sufficient bullion to cover its commitments to its customers. While the evidence on that issue was not without uncertainty, what was tolerably clear, according to Cooke P, was that the bank was in a better position to ascertain particulars of the company's trading methods, and to assess the risks, than were the customers. That being the case it was not inequitable that the customers should have priority over the bank. ${ }^{51}$

In his separate judgment, Gault J agreed with Cooke P's view that the view that the customers and the company stood in a fiduciary relationship. That being the case the company was under a duty to protect the customers' interests by holding sufficient bullion stocks on the customers' behalf. That duty was sufficient to found an equitable proprietary interest in the monies paid to the company and in any products that it might purchase with those monies. Moreover, such an interest could not be defeated by payment of the monies into the company's overdrawn account with its bank if the bank had notice, actual or constructive, of that interest. Further, on his view of the authorities, the customers' equitable proprietary interest could be traced into any assets of the company acquired using monies with which were mixed monies received from the customers and could be enforced by an equitable charge over such assets, including bullion stock held from time to time. ${ }^{52}$

On appeal to the Privy Council, the approach adopted by Cooke P and Gault J was rejected and the dissenting judgment of McKay J upheld. The Privy Council disagreed with Cooke P and Gault J on a number of crucial points. First, their Lordships rejected the conclusion that there was a fiduciary relationship between the company and the customers. On its analysis of the contracts between the company and the customers, the arrangement entered into was a contract of sale by the company to, not a purchase by the company for, the customers. Accordingly, and crucially, the company was free to spend the purchase money it received from the customers as it chose and had

50 Space Investments Limited v Canadian Imperial Bank of Commerce Trust Co (Bahamas) Limited [1986] 3 All ER 75 (PC).

51 Liggett $v$ Kensington, above n 46, 274-5 Cooke P.

52 Ibid, 280-281 Cooke P. 
no trust or fiduciary obligations in respect of them. In turn, although no bullion had been delivered to them, the customers had had the benefit of the contract they had entered into: the contract was simply for the sale of unascertained bullion - no more - and therefore there could not have been any total failure of consideration as had been concluded by Cooke P. Furthermore, because the bullion was unascertained at the time of the contract, it followed that there was no relevant property to which (even if there were a fiduciary or trust-like relationship between the company and its customers) a trust obligation or proprietary fiduciary obligation could attach. In addition, no general principle of unconscionable retention arose as between the competing parties, namely the customers and the bank. By virtue of its debenture, the bank had a prime facie right to the assets of the company at the point at which its floating charge crystallised. Nothing the bank had done affected the validity of its security and it was entitled to rely upon it to secure its interests. Hence, there was no basis on which to justify the intervention of equity on behalf of the customers.

Of interest, in concluding against the customers in Goldcorp, their Lordships "fully acknowledge[d] the indignation of the claimants, caught up in the insolvency of the group of which the Company formed part, on finding that the assurances of a secure protection on the strength of which the abstained from calling for delivery were unfulfilled; and they understand why the Court should strive to alleviate the ensuing hardship. Nevertheless there must be some basis of principle for depriving the Bank of its security and ... none has been shown". 53

Some might suggest that the Privy Council's reversal of the majority's approach in Goldcorp was a setback for the indigenous development of equity and trusts law in New Zealand. I am not sure that it was. Both in the language of his judgment and in his extra-judicial writing about this "fiendishly complicated case", ${ }^{54}$ Robin indicated that he saw the case as "difficult" 55 and far from straightforward. He noted that the issues raised by the facts of the case were ones upon which there were differing responses by leading scholars and that precedents could lead a judge to conclude either way. ${ }^{56}$ His preference for the claims of the customers over those of the bank was a product of the former's almost complete vulnerability to, and lack of acceptance of risk from, the actions of the company and the contrasting (comparatively stronger) ability of the latter to protect itself as a debenture holder, and its acceptance of commercial risk in relation to the company's actions. That view was not shared by the Privy Council (nor indeed by McKay J). It saw the matter as a contest between the bank's valid security and a general (and justified) indignation on the part of the

53 Re Goldcorp Exchange Ltd (in receivership) [1994] 3 NZLR 385, 405 (PC) Lord Mustill.

54 R Cooke "The Place of Equity and Equitable Doctrines in the Contemporary Common Law World: A New Zealand Perspective", above n 2, 33.

55 Ibid, 34.

56 Liggett $v$ Kensington, above n 46, 275 Cooke P. 
customers about their mistreatment which could not, of itself, be converted into some sort of proprietary interest.

The later Court of Appeal decision in Fortex Group (in rec \& liq) v MacIntosh shows that the Privy Council's perspective as to how that contest should be resolved is one that many New Zealand judges would share. ${ }^{57}$ Unfortunately, space constraints do not permit of a full discussion of this post-Cooke decision of the Court of Appeal. In brief, that case, like Goldcorp, involved a contest in respect of the assets of an insolvent company between a bank debenture-holder on the one hand and unsecured creditors, some of the company's employees, on the other. The employees in question had had deductions made from their salaries during the financial year. The money deducted from their salaries was meant to be onsent by the company to the manager of the company superannuation scheme. Instead of onsending the employee contributions, the company made journal entries in respect of the salary deductions and retained the deductions to reduce the size of its overdraft. On the company's collapse the employees sought to assert a constructive trust in respect of the general assets of the company. While successful before the High Court, they failed before a unanimous five member bench of the Court of Appeal which, applying Goldcorp, held that there could be no trust without identifiable trust property; reducing the potential size of the company's overdraft did not create such an asset. In a contest between the employees and the bank it could see no valid basis to deny the latter its ability to rely on its rights at law (the security).

\section{F Property Sharing in De Facto Relationships}

Through the 1980s and 1990s, New Zealand courts were frequently confronted with issues as to how the property affairs of de facto couples should be treated upon the death of one of them or upon the ending of the relationship. ${ }^{58}$ These cases came before the Courts because (a) property (typically the home shared by the de facto couple) was held in the name of one member of the couple; and (b) the statutory community property regime established in the Matrimonial Property Act 1976 did not apply (before 2001 amendments resulting in the renamed Property (Relationships) Act 1976, the 1976 Act only applied to married couples).

In the "de facto" cases, the plaintiff typically sought a declaration that he or she had an equitable interest in the relevant property. In some cases, plaintiffs were able to point to evidence supporting the proposition that there had been an agreement between the parties to the de facto relationship that the property be held on trust in certain shares (often equal shares).

In many cases, however, there was no evidence of an express agreement. In those cases, plaintiffs frequently argued that the courts ought, nonetheless, to impose a constructive trust over

57 Fortex Group (in rec \& liq) v MacIntosh [1998] 3 NZLR 171 (CA). Indeed, in Goldcorp itself McKay J had registered a strong dissent which the Privy Council ultimately upheld.

58 See the useful discussion of the case law by N Peart and G W Austin in Butler, above 7, 1199-1214. 
the property in issue to reflect the contribution made to the acquisition or maintenance of the property, or to reflect the overall sharing nature of the de facto relationship in issue. These submissions were the cause of substantial controversy at High Court level. On the one hand, a group of judges was of the view that equity had no business interfering in the defendant's legal title, absent an agreement of the parties to the contrary. The existence of a de facto relationship was insufficient to justify a reallocation of property rights. On the other hand, another group of judges considered that in light of the increasing trend for de facto relationships and the potential unfairness to the nonproperty holding partner, if his or her contributions to the acquisition and maintenance of the property were not recognised, the constructive trust was as an appropriate tool to secure justice.

In Hayward $v$ Giordiani ${ }^{59}$ the Court of Appeal entered the debate in strong obiter dicta. In his judgment, having considered overseas developments at some length, Cooke P stated his view that: "a function of the Courts must be to develop common law and equity so as to reflect the reasonable dictates of social facts, not to frustrate them", 60 and that the "principles of equity ... cannot have ceased growing at some climactic date in England". ${ }^{61}$ Having considered the overseas authorities and the facts of the particular case, his Honour indicated that had he not found for the plaintiff on the more orthodox imputed common intention trust approach, he "would have been disposed to hold that a constructive trust arose here, flowing from the joint efforts of the parties and reasonable expectations, even if they had not applied their minds to the precise question". 62

In his short concurring judgment, Richardson J pithily stated: ${ }^{63}$

There is considerable force in the argument that given the realities of contemporary family life the property interests of parties who have been cohabiting together outside of marriage should not turn on an elusive and often vain search for indications of a common intention in relation to the property; and that there should be room in the evolution of equitable principles for the imposition of constructive trust to reflect the direct and indirect contributions of the parties to the property which they have when they ceased to live together.

And in similar vein, McMullin $\mathrm{J}$ hinted that he too favoured the broader constructive trust approach. In that regard he stated: ${ }^{64}$

\author{
59 Hayward v Giordani [1983] NZLR 140 (CA). \\ 60 Ibid, 148 Cooke P. \\ 61 Ibid. \\ 62 Ibid. \\ 63 Ibid, 149 Cooke P. \\ 64 Ibid, 153 Cooke P.
}


There seems no good reason why the categories of cases in which the Courts have held trusts to exist should be considered to be closed. This branch of the law is not one where policy considerations should inhibit the Courts from developing it to meet different circumstances in relationships and changing social conditions. The history of equity is a story of evolution.

In a series of further cases, these points were explored further. Of particular significance was the Court of Appeal's decision in Gillies $v$ Keogh, six years after Hayward. ${ }^{65}$ Relevantly, G (a separated woman) and $\mathrm{K}$ (a single man) had a relationship of a little over three years duration. After the first year, $G$ purchased a house in her sole name, using funds from her previous matrimonial property settlement, loans from her father and a friend, and from other borrowings. At all times $\mathrm{G}$ indicated to $\mathrm{K}$ that she regarded the house, which they lived in, as hers. That was the case, notwithstanding that $\mathrm{K}$ had contributed his earnings into a joint account which had been used for household expenses and outgoings in connection with the house and had substantially contributed to work on the house which resulted in its extension, substantial improvement and the development of the garden. The issue for the Court was whether, in light of these circumstances, K could legitimately claim a share in the net equity of the property held in G's name.

In the High Court, Gallen J found that there was no express or implied agreement justifying a trust. Nonetheless he considered that $G$ had been unjustly enriched through K's contribution to outgoings and to his physical work on the house, and awarded him approximately half of the capital gain in respect of the property.

On appeal, the Court of Appeal held for G. In the course of rejecting K's claim that he should have a share in G's house, the Court of Appeal had to consider the juristic basis for the imposition of a constructive trust in the case of de facto relationships and the desirability, or otherwise, of legislative intervention.

On the substantive issue of trusts law, the court was unanimous that it was not appropriate for a court to impose a constructive trust where the party, in whose name legal title was held, had asserted clearly and emphatically throughout the relationship that she did not consider herself bound to yield any interest in the subject property to her partner. While each of the four judges analysed the matter somewhat differently, the net effect was that each was satisfied that $\mathrm{K}$ could have had no reasonable expectation of an interest in the subject property.

In their judgments, Richardson $\mathrm{J}$ and Casey $\mathrm{J}$ expressed concern and dissatisfaction at the state of the law. Richardson J remarked that it was not possible for judges to equate de facto relationships and marriages for the purposes of applying matrimonial property principles as to do so "would involve unwarranted judicial legislation". ${ }^{66}$ Having noted a number of "serious practical problems"

65 Gillies v Keogh [1989] 2 NZLR 327 (CA).

66 Ibid, 348 Richardson J. 
that continuation with the application of equitable principles by the courts to de facto property disputes involved, ${ }^{67}$ His Honour concluded: ${ }^{68}$

In an area of family relations which is now so basic to the functioning of society there is, I believe, much force in the argument that a statutory code enacted after appropriate consideration of all the public policy interests involved, and providing a clear statement of the principles to be applied, would be a better basis for allocating property interests than continued reliance on the innovative skills of the judiciary in developing and adapting equitable principles.

In his judgment, Casey J accepted that the use of "old [equitable] remedies"69 on a case by case basis had achieved results which appeared to be working with reasonable success in dealing with contributions to property in conventional de facto situations. Nonetheless, he expressed considerable reservations about extending proprietary interests to recognise services provided to fulfil family functions similar to those expected of legal spouses. That was because such matters would raise "questions of definition and social policy which are generally beyond the Court's experience to assess or deal with adequately under existing law in the field". ${ }^{70}$ Like Richardson $\mathrm{J}$, he called for "the certainty of legislation which at least defines socially acceptable boundaries and general principles for the exercise of jurisdiction [in respect of such matters]". ${ }^{71}$

The Court of Appeal returned to the issue a further six years later in Lankow $v$ Rose. ${ }^{72}$ There the parties had lived in a de facto relationship for approximately 10 years. At the end of the relationship the value of the respective parties' assets was \$30,000 (plaintiff's) and \$650,000 (defendant's). Throughout the relationship, however, the plaintiff (the female partner) had made substantial contributions to the repayments on the various properties held in the defendant's name, including mortgage payments and household outgoings. Counsel for the defendant submitted strongly that it was improper for the Courts to rely on equitable principles to seek to deprive the legal owner of property of his or her rights, other than by reference to a contract, or express, implied or resulting trust, or, perhaps, proprietary estoppel. ${ }^{73}$

In the High Court, Ellis J had awarded the plaintiff a half-share in the principal residence and in a number of shared chattels. On appeal, the Court of Appeal largely upheld that decision. In doing

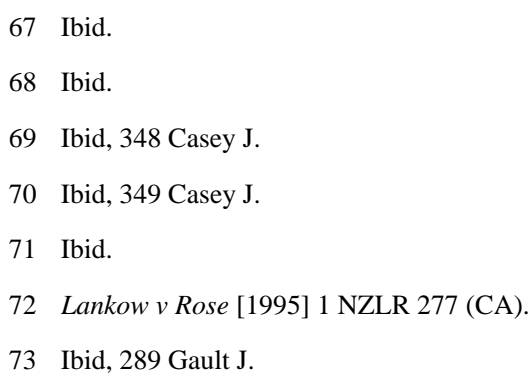


so, however, a number of the judges made important observations as to the proper role of equity in responding to the continued problem of de facto property disputes and the desirability of legislative reform.

In his judgment, for example, Cooke P noted the absence of legislation, accepting that division of de facto property was "a controversial field". ${ }^{74}$ In the absence of legislation, the courts "have to do their best to achieve justice with the available judicial instruments. These include the recognition or imposition of constructive trusts". ${ }^{75}$ Notwithstanding his view that judges had "achieved workable and wise solutions" relying on trust principles, Cooke P acknowledged that "legislation laying down some more hard-and-fast approach might be desirable, not only theoretically but in practice." 76

In similar vein, Hardie Boys $\mathrm{J}$ emphasised that it was inappropriate to develop the principles of constructive trusts in de facto property cases by analogy with the approach under the Matrimonial Property Act. In particular, his Honour expressed the view that it would not be reasonable for a de facto partner to expect to share in assets held in his or her partner's name in the same way that married couples do: "if the distinction between the two categories [ie married and de facto couples] is to become one of form only, that is a revolutionary step which in my view only Parliament can take."77 That being the case, it was not open to the court to treat contributions made in a de facto relationship in the same way that it could look to contributions to a marriage partnership under the Matrimonial Property Act. Accordingly, "for a constructive trust the Court must look to contributions to assets." 78

In his judgment, Gault $\mathrm{J}$ noted that the courts throughout the Commonwealth relied on the constructive trusts in de facto property cases so as to avoid the injustice that they had identified as arising for parties disadvantaged on the termination on de facto unions. He expressed his clear view that "such developments have been appropriate responses to social circumstances and attitudes."79

Tipping $\mathrm{J}$ too emphasised the limitations applicable to constructive trust principles in the field of de facto property disputes. He stated in clear terms that "it is not enough for the claimant to show a contribution to the relationship. In order to be awarded a beneficial interest in property owned in law

74 Ibid, 280 Cooke P.

75 Ibid.

76 Ibid.

77 Ibid, 286 Hardie Boys J.

78 Ibid.

79 Ibid, 289 Gault J. 
by the defendant, the claimant must first show some contribution, direct or indirect, to the property at issue." 80

The de facto cases illustrate a number of important points. First, equity is sufficiently flexible to adapt to modern conditions. This links to Cooke P's statement in Day v Mead that equity has not petrified. Secondly, its ability to adapt, and its flexibility, is constrained. In particular, trusts doctrine and the constraints imposed by legitimate judicial methodology mean that the factors which justify equitable intervention in de facto cases are limited; in turn, the concomitant limits on the type of relief that equity can grant also restrict its ability to give a total response to the social phenomenon of de facto relationships. Thirdly, there will be situations where, in the absence of parliamentary intervention, judges are required to respond. Those responses, however, are not necessarily the only possible responses, nor will they necessarily be the best responses viewed from a social policy perspective. In turn, judicial solutions should not be seen as sacred; legislative intervention may indeed be preferable, particularly if property rights are in issue, the problem is polycentric, and the resolution of those policy factors is not obvious (or, at least, there is a range of reasonable responses).

\section{G Bribes Taken by Fiduciaries: Attorney General for Hong Kong v Reid}

The last in this survey of significant equity and trusts cases of the Cooke era is Attorney General for Hong Kong $v$ Reid. ${ }^{81}$ It involved the vexed question of the duty of a fiduciary to account for bribes received during the holding of office. In that case $\mathrm{R}$ had received a bribe during his time as head of the Hong Kong Commercial Crime Unit. He used some of the bribe money to acquire property in New Zealand. The Government of Hong Kong asserted that it had a proprietary interest in the bribes and any substituted assets. Longstanding authority, Lister \& Co v Stubbs, ${ }^{82}$ was against the proposition that any proprietary interest in the New Zealand properties could arise. In that case the English Court of Appeal had held that though it was improper for a fiduciary to accept a bribe, receipt of a bribe by a fiduciary only created a creditor-debtor relationship in the amount of the bribe; it did not entitle the beneficiary to claim a proprietary interest in respect of the bribe money or any substituted asset.

In the High Court Penlington J applied Lister and rejected the Attorney General's claim. The Attorney General appealed to the Court of Appeal. Writing for himself, Hardie Boys and Gault JJ, Richardson J upheld the approach set out in Lister. Having considered the case law since Lister, Richardson J concluded that the Court could "see no justification for not concluding that Lister \& Co $v$ Stubbs is the law of England". ${ }^{83}$ Although acknowledging that the decision had its academic

80 Ibid, 294 Tipping J.

81 Attorney General for Hong Kong v Reid [1992] 2 NZLR 385 (CA).

82 Lister \& Co v Stubbs (1890) 45 Ch D 1 (CA).

83 Attorney General for Hong Kong v Reid, above n 81, 391 Richardson J. 
detractors (and some supporters), ${ }^{84}$ Richardson J noted that the criticisms tended to focus "on policy concerns and alleged inconsistencies with the broad sweep of constructive trust and unjust enrichment developments in their relation to profits flowing from the misuse of position". 85 There was no suggestion by the academic detractors that Lister was inconsistent with precedent. That being the case, the argument for the Attorney General reduced itself to being one that Lister "was anomalous and contrary to developments in the law of constructive trusts. In effect we are asked to rule that Lister \& Co $v$ Stubbs is not good law". ${ }^{86}$ The Court of Appeal refused to so hold. The reason was that in light of the Privy Council's decision to reverse the Court of Appeal's decision in $O^{\prime}$ Connor v Hart, ${ }^{87}$ it was not appropriate for the New Zealand Court of Appeal to decline to apply settled principles of English law, in the absence of local conditions calling for a different approach in New Zealand from that taken in England. ${ }^{88}$

On further appeal, the Privy Council overruled Lister. The Privy Council acknowledged that it had always been assumed and asserted that the law on the subject of bribes received by fiduciaries was definitively settled by that decision. That was no reason why its persuasiveness should not be questioned. Having opened the way for a review of Lister, the Privy Council concluded that notwithstanding its antiquity and the fact that it had been followed in numerous subsequent cases, it could not stand. Why not? A return to the basic object of fiduciary law provided the answer: ${ }^{89}$

The decision in Lister $v$ Stubbs is not consistent with the principles that a fiduciary must not be allowed to benefit from his own breach of duty, that the fiduciary should account for the bribe as soon as he receives it and that equity regards as done that which ought to be done. From these principles it would appear to follow that the bribe and the property from time to time representing the bribe are held on a constructive trust for the person injured.

Reid, therefore, effectively endorsed the approach which Robin and his colleagues had been pursuing in New Zealand equity cases in the 1980s and early 1990s: the point of departure in determining the correct resolution of a claim based on equity is to identify the object of the doctrine in issue, not necessarily to simply trawl through the cases shorn of informing principle. There must, therefore, have been some level of irony felt back in Wellington that one of the reasons why the Court of Appeal did not feel able to undertake a similar exercise itself in Reid was that in the mid1980s in O'Connor $v$ Hart (a case on the equitable doctrine of unconscionable bargains) the Privy

84 Ibid.

85 Ibid, 391-392 Richardson J.

86 Ibid, 392 Richardson J.

87 O’Connor v Hart [1985] 1 NZLR 159 (PC).

88 Attorney General for Hong Kong v Reid, above n 81, 392.

89 Attorney General for Hong Kong v Reid [1994] 1 NZLR 1, 8 (PC) Lord Templeman. 
Council had criticised the Court of Appeal when it had departed from well-settled principles of English law!

\section{CONCLUSION}

The contemporary equitable scene, in New Zealand at least, is much changed from that which presented itself in the first part of the last century. That is due in no small measure to the contribution that Robin and his erstwhile Court of Appeal colleagues made to the modern evolution and application of equitable principle. Of course, as we have seen, not everyone welcomed the efforts of Robin and his colleagues. The comments in the preface to the 2002 edition of Australia's leading text on equity, Meagher, Gummow and Lehane's Equity: Doctrines and Remedies, illustrate that for those in any doubt: ${ }^{90}$

In New Zealand, the prospect of any principled development of equitable principle seems remote short of a revolution on the Court of Appeal. The blame is largely attributable to Lord Cooke's misguided endeavours. That one man could, in a few years, cause such destruction exposes the fragility of contemporary legal systems and the need for vigilant exposure and rooting out of error.

But contrary to the view which these learned authors espouse, the contribution of Robin Cooke and his colleagues to equitable principle and doctrine has been largely positive, guided as it was by the identification of the true purposes informing equitable intervention.

As our brief survey of significant cases from the Cooke era shows a number of themes emerged to guide the rational development of New Zealand equity and trusts law:

(a) The fundamental ongoing justification for equity, as a body of law, is to ensure justice is done between individuals. To that end, it is important to identify what the purpose behind a particular equitable doctrine is.

(b) Distinctions between common law causes of action and remedies and equitable causes of action and remedies cannot be justified by reference to history alone.

(c) The purpose of equity continues to be to ameliorate the rigidity of the common law, but equally equity itself must avoid undue rigidity. In any particular case, identifying what would be "undue" rigidity can be a challenge.

(d) Where common law and equitable causes of action, remedies or defences have the same or similar purposes then equity can legitimately learn and take from common law analogues.

(e) There are, however, limits to what can be legitimately done by courts in the name of equity in order to achieve justice. In some cases the nature of judicial law-making and the

90 Meagher, Heydon and Leeming, above n 19, xi. It should be noted that the authors' focus on Robin ignores the fact that many of the decisions which they criticise were ones in which others participated - he was not able to act alone. 
limits imposed by existing doctrines mean that certain steps can only be taken by the legislature: equity's focus on justice in the individual case cannot be invoked to assume a role better suited to the legislative process. Equally, in striking the balance between competing claims to property where the conscience of the defendant is clean it is unlikely to be appropriate for equity to be relied upon to deprive the legal owner of his or her property rights in favour of another.

Of course, as in any human endeavour, the journey has not been without its bumps: on occasions the direction taken by the New Zealand Court of Appeal suffered reversal by the Privy Council; on others the Privy Council considered that the New Zealand Court of Appeal had not been sufficiently bold. But the trend has been clear: the evolution of a system of equitable doctrine and remedies that is more principled in focus and simpler to state. The result is that in New Zealand equity and trusts law is now more readily understood by lawyers who have to advise their clients and mount proceedings, and by judges who need to apply the doctrines in disputes between real parties. That is a testament to the leadership and example provided by Robin Cooke. 